\title{
Genetic diversity of polysporic isolates of Moniliophthora perniciosa (Tricholomataceae)
}

\author{
L.F.R. Ferreira' ${ }^{1}$, K.M.R. Duarte ${ }^{2}$, L.H. Gomes ${ }^{3}$, R.S. Carvalho ${ }^{3}$, \\ G.A. Leal Junior ${ }^{4}$, M.M. Aguiar ${ }^{5}$, R.D. Armas ${ }^{6}$ and F.C.A. Tavares ${ }^{3}$ \\ ${ }^{1}$ Laboratório de Ecologia Aplicada, Centro de Energia Nuclear na Agricultura, \\ Universidade de São Paulo, Piracicaba, SP, Brasil \\ ${ }^{2}$ Instituto de Zootecnia, Agência Paulista de Tecnologia dos Agronegócios, \\ Nova Odessa, SP, Brasil \\ ${ }^{3}$ Departamento de Genética, Escola Superior de Agricultura "Luiz de Queiroz", \\ Universidade de São Paulo, Piracicaba, SP, Brasil \\ ${ }^{4}$ Departamento de Genética Molecular de Plantas, \\ Centro de Energia Nuclear na Agricultura, Universidade de São Paulo, \\ Piracicaba, SP, Brasil \\ ${ }^{5}$ Department of Cell and Molecular Biology, Colorado State University, \\ Fort Collins, CO, USA \\ ${ }^{6}$ Departamento de Solos e Nutrição de Plantas, \\ Escola Superior de Agricultura "Luiz de Queiroz", \\ Universidade de São Paulo, Piracicaba, SP, Brasil \\ Corresponding author: L.F.R. Ferreira \\ E-mail: romanholobio@gmail.com
}

Genet. Mol. Res. 11 (3): 2559-2568 (2012)

Received October 27, 2011

Accepted May 15, 2012

Published July 10, 2012

DOI http://dx.doi.org/10.4238/2012.July.10.11

\begin{abstract}
The causal agent of witches' broom disease, Moniliophthora perniciosa is a hemibiotrophic and endemic fungus of the Amazon basin and the most important cocoa disease in Brazil. The purpose of this study was to analyze the genetic diversity of polysporic isolates of M. perniciosa to evaluate the adaptation of the pathogen from different Brazilian regions and its association with different hosts. Polysporic isolates obtained previously in potato dextrose agar cultures of M. perniciosa from
\end{abstract}


different Brazilian states and different hosts (Theobroma cacao, Solanum cernuum, S. paniculatum, S. lycocarpum, Solanum sp, and others) were analyzed by somatic compatibility grouping where the mycelium interactions were distinguished after 4-8 weeks of confrontation between the different isolates of $M$. perniciosa based on the precipitation line in the transition zone and by protein electrophoresis through SDS-PAGE. The diversity of polysporic isolates of $M$. perniciosa was grouped according to geographic proximity and respective hosts. The great genetic diversity of M. perniciosa strains from different Brazilian states and hosts favored adaptation in unusual environments and dissemination at long distances generating new biotypes.

Key words: Somatic compatibility; Protein electrophoresis; Witches' broom disease; Genetic variability

\section{INTRODUCTION}

The fungus Moniliophthora perniciosa (Aime and Phillips-Mora), formerly Crinipellis perniciosa (Stahel) Singer, is the causal agent of witches' broom disease in cocoa and is pathogenic to other species (mainly from Solanaceae) (Bastos and Evans, 1985). This fungus is endemic to the Amazon forest and causes considerable reduction in cocoa yields in South America (Bolivia, Ecuador, Peru, and Venezuela) and the Caribbean Islands (Trinidad, Tobago, and Granada). In May 1989, the fungus was detected in cocoa plantations in Bahia State, a major region of Brazilian cocoa production (Pereira et al., 1989). Damage from this organism can reduce yields as much as $90 \%$; Bahia producers reported a $75 \%$ yield decrease (Andebrhan, et al., 1998), leading to the extinction of large productive areas and the conversion of native forest to cattle farms.

Control of the fungus is achieved with physical, chemical, and biological methods, and an emphasis has been placed on the development of integrated and resistant strains that provide cheaper, efficient, and affordable management for farmers (Purdy and Schmidt, 1996). Efforts toward making genetic improvements in cocoa plants have been insignificant compared to those to develop other methods of control owing to the unknown genetic basis of resistance and mechanism of plant-pathogen interaction (Wheeler, 1976; Agrios, 1988) combined with poor identification of resistant plant isolates through artificial inoculation, large pathogen variability, and a lack of known pathotypes (Silva et al., 1998; Meinhardt et al., 2008).

Sexual multiplication of M. perniciosa leads to genetic variations, and pathogen genetic exchange into infected tissues results in multiple host infections. Colonization throughout various hosts increases genotype selection and high variability (Meinhardt et al., 2008).

The intraspecific classification of M. perniciosa has been based on pathogenicity data (Hedger et al., 1987; Wheeler and Mepsted, 1988) identifying 4 groups: 1) Malvaceae (biotype C), which infects mainly Theobroma and Herrania spp, causing economic damage (Evans, 1978); 2) Solanaceae group (biotype S), which infects host species from Solanum spp (Bastos and Evans, 1985; Purdy and Schmidt, 1996); 3) biotype H, which has recently been identified and infects Heteropterys acutifolia (Malpighiaceae) (Resende et al., 2000; Griffith et al., 2003), and 4) biotype $\mathrm{L}$, which is saprophytic (Lianas) and colonizes a vast number of substrates, alive or dead, especially the species Arrabidaea verrucosa (Standl.) A.H. Gentry (Bignoniaceae) 
(Evans, 1978; Hedger et al., 1987; Griffith and Hedger, 1994a,b; Arruda et al., 2003).

Many native M. perniciosa host species, such as Solanum spp have been identified in several regions of Brazil, including Minas Gerais State (Evans and Barreto, 1996; Pereira et al., 1998), Amazonas (Bastos and Evans, 1985), Tocantins, Rondonia, Mato Grosso do Sul, Mato Grosso, Goiás, and Distrito Federal (Pereira et al., 1997; Resende et al., 1997). In the Malpighiaceae family, H. acutifolia, a common species in the riparian forests in Minas Gerais State, is also a M. perniciosa host (Resende et al., 2000). In 1985, the occurrence of M. perniciosa in Bixa orellana, which belongs to the Bixaceae family, was documented in Pará State (Bastos and Andebrhan, 1986; Arruda et al., 2003).

The variability characterization of M. perniciosa has been based on morphologic and cultural characteristics, somatic compatibility (SCG), molecular analysis, and biochemistry relationships with Theobroma cocoa and other Theobroma spp (Hedger et al., 1987; McGeary and Wheeler, 1988; Wheeler and Mepsted, 1988; Griffith and Hedger, 1994a; Arruda et al., 2003; Lana et al., 2011). Anastomosis between mycelium from different origins might give rise to a heterokaryon appearance in the saprophytic mycelium, and variability subsequently increases in the next basidiospore generation. This theory for variability has fundamental importance because knowledge of pathogen diversity potential is important for planning integrated control programs for witches' broom disease, including resistance (Thomsen and Koch, 1999).

Sodium dodecyl sulfate-polyacrylamide gel electrophoresis (SDS-PAGE), especially when combined with other study methods such as mycelial interaction, might be a useful tool for studies of fungi variability (Novak and Kohn, 1988). Studies of taxonomy, variability, and host specificity for several isolates of $M$. perniciosa can be helpful in the development of efficient control strategies. Therefore, we studied M. perniciosa genetic diversity grades associated with several hosts in various Brazilian regions to identify preferential or differential association signs between pathogens and hosts.

\section{MATERIAL AND METHODS}

\section{Isolation of $M$. perniciosa strains}

M. perniciosa isolates were obtained from various hosts (T. cacao; Solanum cernuum; $S$. lycocarpum; S. paniculatum; Solanun spp, and lianas). Among the T. cacao isolates, 9 were from Amazonic states (Rondonia, Amazonas, Pará, and Mato Grosso) and one was from Bahia State. The Solanaceae isolates were from Minas Gerais, São Paulo, and Bahia States (Table 1).

\section{Selection and maintenance of polysporic cultures}

Mycelium growth in agar-wheat-dextrose culture medium was obtained using a disk of polysporic culture previously cultivated in a medium composed of $20 \%$ potato broth, $2 \%$ dextrose, and $2 \%$ agar in distilled water, which was placed on Petri dishes ( $9 \mathrm{~cm}$ in diameter) containing $10 \mathrm{~mL}$ of culture medium.

After polysporic M. perniciosa culture selection from various hosts, 7-mm disk transfers were made from the edge of the colonies to fresh medium. The isolates were maintained in the dark in a biochemical oxygen demand incubator with a controlled temperature $\left(26^{\circ} \mathrm{C}\right)$ in agar wheat-bran-dextrose medium covered with mineral oil. 
Table 1. Moniliophthora perniciosa (MP) isolates from different hosts and regions of collection.

\begin{tabular}{llll}
\hline Species & Code & Hosts & Locality \\
\hline Moniliophthora perniciosa & MP 1 & Theobroma cacao & Marituba/PA \\
& MP 2 & T. cacao & Belém/PA \\
& MP 3 & T. cacao & Altamira/PA \\
& MP 4 & T. cacao & Medicelândia/PA \\
MP 5 & T. cacao & Ouro Preto/RO \\
& MPriquemes/RO \\
& MP 7 & T. cacao & Ji-Paraná/RO \\
MP 8 & T. cacao & Manaus/AM \\
& T. cacao & Alta Floresta/MT \\
& MP 9 & T. cacao & Bahia \\
& MP 10 & T. cacao & Bahia \\
MP 11 & T. cacao & Minas Gerais \\
MP 12 & Solanum cernuum & Rio Pomba/MG \\
& MP 13 & S. cernuum & Viçosa/MG \\
& MP 14 & S. lycocarpum & Coimbra/MG \\
MP 15 & S. lycocarpum & Gandu/BA \\
MP 16 & S. paniculatum & Sauo Paulo \\
MP 17 & Solanum sp & Viçosa/MG \\
MP 18 & Solanaceae & - \\
\hline MP 19 & Liana (Harry Evans) & - \\
\hline
\end{tabular}

\section{SCG tests among M. perniciosa isolates}

Disks $(7 \mathrm{~mm})$ from polysporic culture isolates were compared in Petri dishes $(9 \mathrm{~cm}$ in diameter) with $2 \mathrm{~cm}$ in distance from one another using the same medium. The comparisons were performed in triplicate and incubated at $26^{\circ} \mathrm{C}$ for $4-8$ weeks. After growing, the colonies were assessed for compatibility based on the precipitation line in the transition zone. The compatibility test data analysis was performed with the NTSYS software using the unweighted pair group method with arithmetic mean algorithm for isolates from the various regions and hosts. Dendograms were then constructed.

\section{Protein profile of $M$. perniciosa isolates}

Analyses of the total protein profile were performed using SDS-PAGE to confirm somatic incompatibility data. Gel optimization was carried out according to Laemmli (1970) and silver staining according to Gomes et al. (2000b) on an 18-cm gel. The protein concentration was determined previously with the Bradford (1976) test in microplates for all samples of M. perniciosa.

The samples were added to the vessels and covered with running buffer added to the top and bottom vessels. The electrophoresis was performed at $20 \mathrm{~mA}$ and $80 \mathrm{mV}$ for the separating gel and $50 \mathrm{~mA}$ and $200 \mathrm{mV}$ for the resolving gel.

Silver staining was carried out until the bands appeared. The data analysis was the same as that of the compatibility test using NTSYS (unweighted pair group method with arithmetic mean) to compare isolates from the various regions and hosts and construct a dendrogram.

\section{RESULTS}

\section{Somatic compatibility}

In this study, two kinds of mycelial interactions were distinguished in the confrontation 
of the M. perniciosa isolates in the culture medium after 2 months' growth. The interactions were the following: 1) linkage between mycelium, resulting in the joining of the 2 colonies with uniform characteristics, and 2) mycelial interaction in the intersectional region in the contact zone with somatic incompatibility (Figure 1). Based on analysis of isolate compatibility, 2 dendrograms were built for M. perniciosa strains and their hosts from various locations in Brazil.
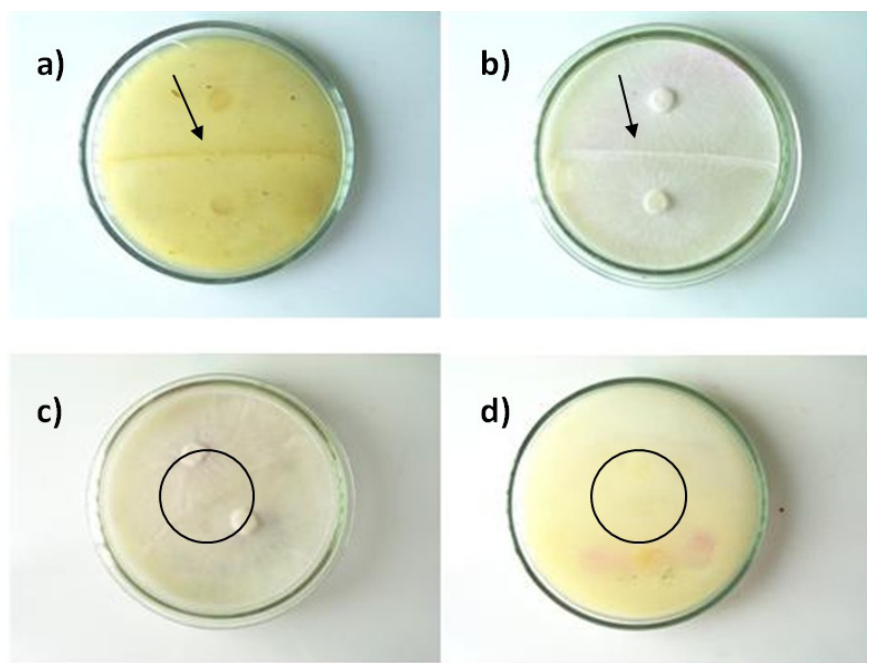

Figure 1. Compatibility and antagonism reactions between different Moniliophthora perniciosa isolates on Petri dishes containing wheat bran and dextrose, showing incompatibility (a and b) with pigmented and compact zone in the line intersection division and intermingling mycelial zone without pigmentation zone showing compatibility reaction (c and $\mathbf{d})$.

The analysis of the M. perniciosa strains isolated in the first dendrogram identified 3 groups: 1) strains from Rondônia State (Ariquemes, Ouro Preto D’Oeste) and Pará State (Altamira, Belém, and Marituba); 2) strains isolated in Rondônia State (Ji-Paraná), Pará (Medicelândia), and Amazonas (Manaus); and 3) the strain from Mato Grosso State (Figure 2). The second dendrogram produced 2 large groups: 1) strains from Bahia, Minas Gerais, São Paulo, Mato Grosso, and Rondonia, and 2) the Pará State strains (Figure 3).

The highest genetic similarity was 0.929 in the T. cacao isolates from Bahia and between the isolates S. lycocarpum from Coimbra (Minas Gerais) and S. paniculatum from Gandú (Bahia State) (see Figure 3). These values indicate that the isolates present similar genotypic characteristics and that those from Minas Gerais might have originated in the Bahia isolates. The isolates of T. cacao from Rondônia State (Ariquemes and Ouro Preto D'Oeste) and Pará State (Altamira, Belém, and Marituba) were combined into a subgroup, demonstrating that the distance of the origin region had selective pressure of the same magnitude (see Figure 2).

\section{Protein profile}

Using the protein profiles of the isolates, we obtained 3 groups based in host and origin: 1) the T. cacao isolate from Ouro Preto D'Oeste; 2) T. cacao isolates from Bahia and several Solanaceae isolates from Minas Gerais, Bahia, and São Paulo State, and 3) the isolate from lianas. 


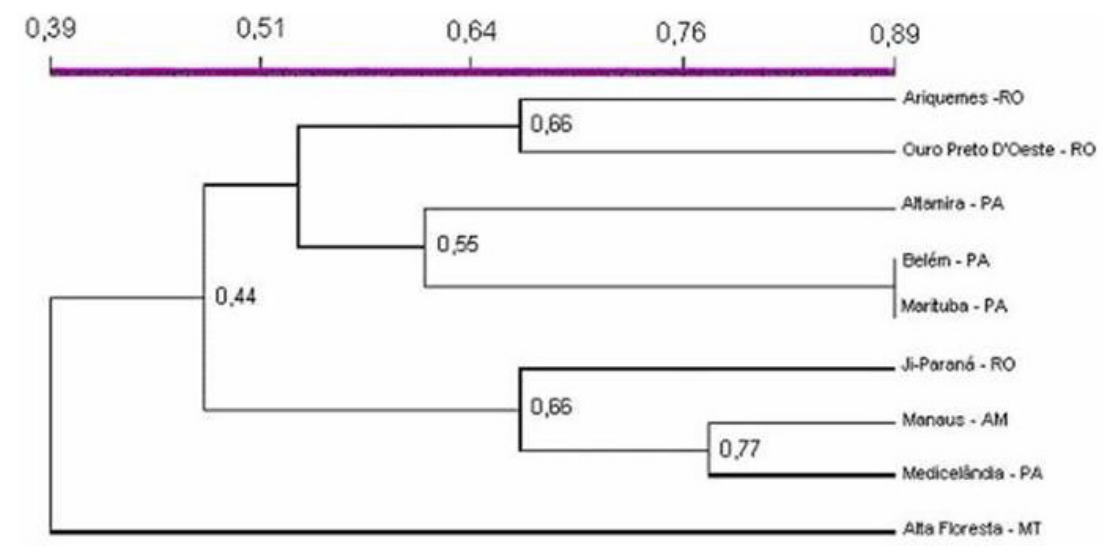

Figure 2. Grouping analysis of nine Moniliophthora perniciosa isolates of Theobroma cacao L. from Amazon region based on the incompatibility somatic test.

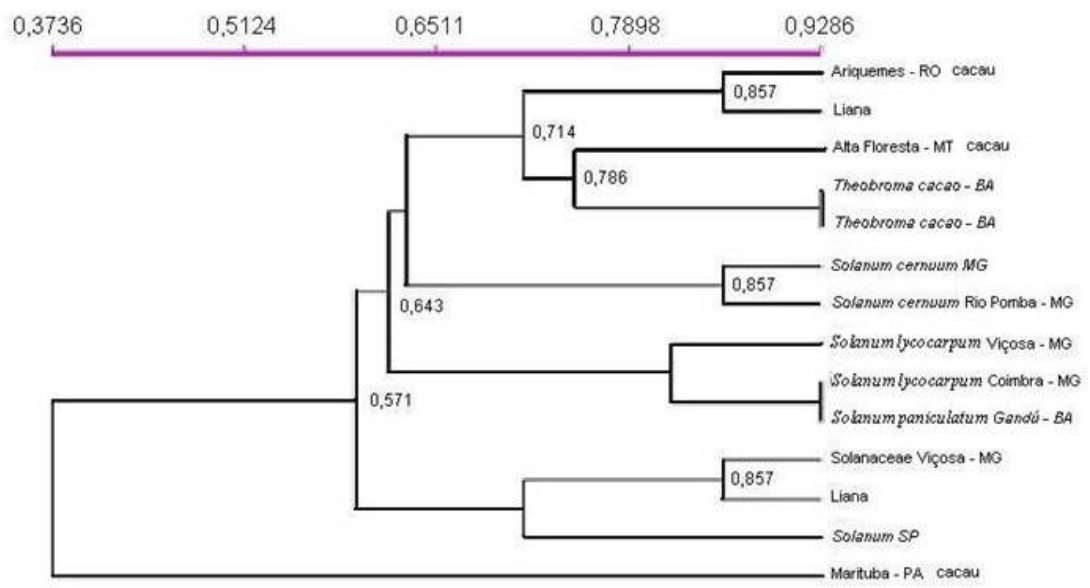

Figure 3. Dendrogram of Moniliophthora perniciosa grouping based on the somatic incompatibility from different hosts and places. Liana species donated by Harry Evans.

\section{DISCUSSION}

According to Jiménez et al. (2002), 2 types of mycelia interactions are possible. In the first, a linkage occurs between mycelium, joining the 2 colonies with uniform characteristics. In the second, an intensity gradient develops at the intersectional region, in which the region of lower intensity is characterized by small lines near the contact zone (May, 1988; MacCabe et al., 1999; Pilotti et al, 2002; Hamidson and Naito, 2004). Conversely, regions of strong intensity are characterized by more compact lines of mycelium. The initially weak pigmentation changes to a dark brown in response to the abortion of cellular fusion demonstrating that the 2 mycelium types do not share genetic homogeneity, complicating the 
combination of the genotypes in the same cytoplasm (Dahlberg, 1995).

According to the compatibility somatic analysis, a cluster of 2 strains from Rondônia State (Ariquemes and Ouro Preto D'Oeste) and 3 strains from Pará State (Altamira, Belém, and Marituba) was possible. These results agree with those of Andebrhan and Furtek (1994), who have reported that the strains from Pará State do not permit differentiation of place or host. They have suggested that geographic proximity and similar environmental conditions result in the multiple infection of the host by the isolates. However, Andebrhan et al. (1998), using in vitro and in vivo studies, observed genetic variation between the M. perniciosa isolates from cacao in several locations in Rondônia State.

A biotype $\mathrm{B}$ isolate has been found infecting a plantation of $B$. orellana adjacent to a cacao farm in Bahia. The authors reported that this isolate was unable to complete its life cycle on $B$. orellana, and the isolate was later proven to be genetically identical to biotype $\mathrm{C}$ isolates found in Bahia (Bastos and Andebrhan, 1986; Griffith and Hedger, 1994a). Therefore, Meinhardt et al. (2008) do not consider biotype B a distinct subgroup of this species.

Random amplified polymorphic DNA (RAPD) genotyping has revealed that biotype $\mathrm{C}$ isolates from Bahia grouped with B and S isolates nearby, suggesting a possible "jump" of isolates to alternative host plants (Andebrhan and Furtek, 1994). RAPD analysis performed by Andebrhan et al. (1999) has shown that isolates from Bahia formed 2 distinct groups, with some isolates grouping with C-biotypes from the Amazon, but not with the S- or B-biotypes. These 2 groups appeared to give credibility to reports of 2 independent introductions into the State of Bahia, leading the authors to conclude that witches' broom disease in Bahia was introduced from Amazonian isolates (Meinhardt et al., 2008).

According to Liberato et al. (1995), the principle of all agglomerative methods is similar and begins with the similarity and dissimilarity matrix between the components of a population and ends with a dendrogram representing the final results graphically. Analysis of the dendrogram of the SCG test showed that most isolates displayed high genetic divergence associated with heterogeneity between isolates and hosts. The genetic similarity variation was 0.143 to 0.929 (percentage of genetic similarity). Based in these results we assume that a large variation in the genetic similarity between the isolates in the same region and those of other regions means that the biotypes have high adaptability with a high inability for colonization in the fungi.

These results agreed with those of studies reported by Yamada et al. (1998) and Gomes et al. (2000a), who have observed that isolates from the same geographic region must be genetically closer. However, the low genetic similarity between M. perniciosa strains from the same region was observed by Andebrhan and Furtek (1994) for different isolates collected less than $2 \mathrm{~km}$ from one another in the Brazilian Amazon and by Viana-Júnior (2001), who found low genetic similarity (0.1429) between Herrania and Theobroma bicolor from Pará State, showing that environmental conditions permit the coexistence of various strains produced through mutation or genetic recombination in the absence of selective pressure.

Results obtained through molecular analysis using RAPD of M. perniciosa strains of different hosts from the Amazon region suggest that geographic distance is more relevant than the host for the establishment of genetic similarity between different isolates of M. perniciosa (Andebrhan and Furtek 1994). Three groups were built: 1) Pará isolates composed by Herrania sp, Theobroma grandiflorum, T. cacao, Theobroma obovatum, and Theobroma subincanum; 2) isolates of T. cacao and B. orellana, and 3) the only isolate of Solanaceae (Solanum rugosum) from Amazonas State. Similar results were obtained from the 2 other compatibility 
tests that were performed, with clusters based on geographic proximity (see Figures 2 and 3).

Geographic distance might determine the genetic variation of a pathogen because isolates from different regions were divergent in analyses with SCG. The same results were reported by Hedger et al. (1987), who have demonstrated a divergence in the M. perniciosa population structure (biotypes L and C) in Ecuador (Pichilingue) and Brazil (Pará) in Petri dishes comparisons ( $\mathrm{SCG}$ ), and inside biotype $\mathrm{C}$ from Ecuador and Brazil.

Andebrhan et al. (1998), using SCG groups, identified 2 fungi groups-one composed of the isolates from Ouro Preto D'Oeste and Jaru cities and one composed of isolates from the cities of Cacoal and Ariquemes (Rondônia State) - demonstrating the existence of variability among $M$. perniciosa groups isolated in the same geographic region. This structural model was observed in the present study, with genetic variation among Solanaceae isolates from various regions of Minas Gerais, including S. lycocarpum (Viçosa), S. lycocarpum (Coimbra), and S. cernuum (Rio Pomba, Minas Gerais; see Figure 3).

Griffith and Hedger (1994a) have suggested that biotype C did not exist before the $T$. cacao culture in the Amazon region and that the lower variability between their strains (compared with those of biotype L) found only in Amazonas State suggests that a recent origin and new selective forces caused by T. cacao monoculture have resulted in this evolution. These relationships were observed in SCG data of mitochondrial DNA polymorphism (Griffith and Hedger, 1994a,b).

The protein profile results of the 3 isolates of Solanaceae from 3 Minas Gerais State cities (Viçosa, Coimbra, and Rio Pomba) that are geographically closer (Figure 4) agree with results of studies performed by Yamada et al. (1998), Gomes et al. (2000a), and Hedger et al. (1987), which have shown that isolates from a geographic region must be genetically closer. The analysis of the protein profiles generated using NTSYS with isolates from various regions and hosts were similar to the results obtained with SCG tests, demonstrating the importance of the use of protein profiles (SDS-PAGE) for pathogen variability studies (Novak and Kohn, 1988).

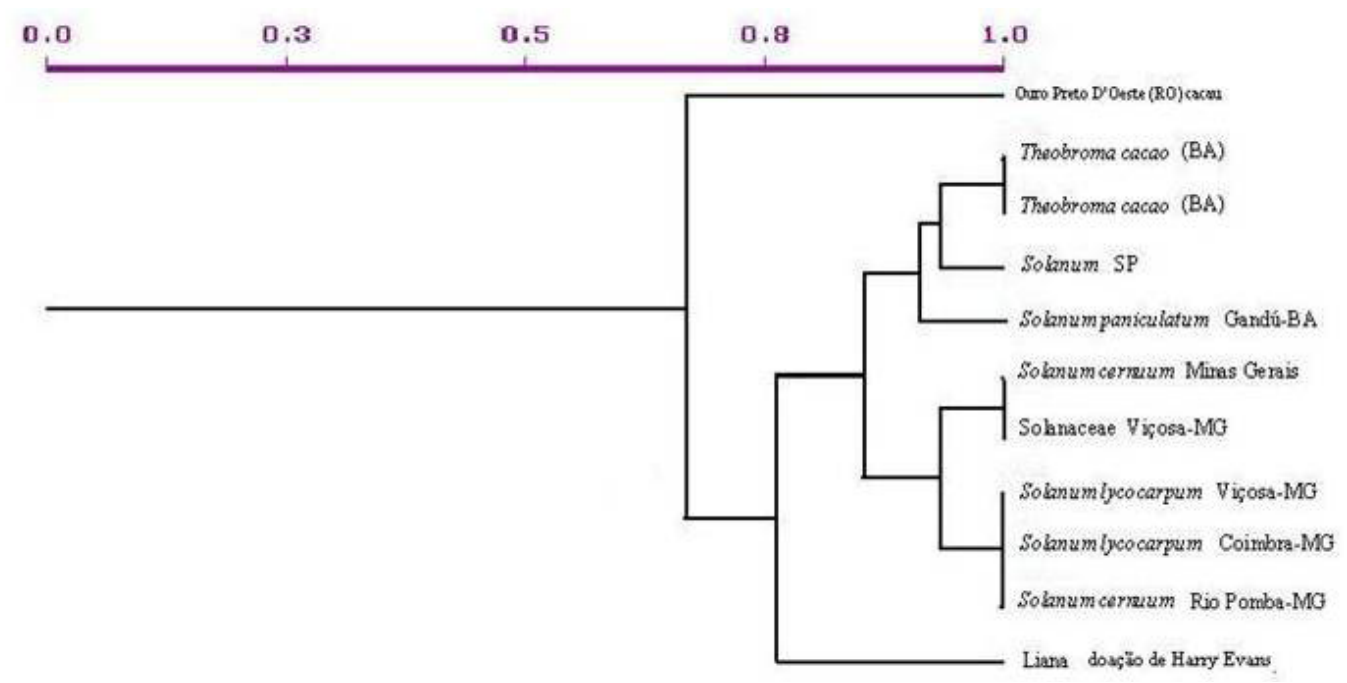

Figure 4. Dendrogram of 11 Moniliophthora perniciosa isolates from different hosts and places, based on bands analysis with the NTSYS software. 
The Solanum (Minas Gerais) and cacao species (Marituba-Pará) showed lower genetic similarity, indicating that a different selection was present in each location with a different biotype selection. High genetic similarity occurred between the cocoa isolates from Bahia and between the Solanaceae species from Minas Gerais and Bahia States, both close states. We demonstrated a strong colonization inability in fungi in different hosts, which influenced other factors such as dispersion, colonization, and hardness.

SCG was efficient for genetic diversity studies of $M$. perniciosa polysporic isolates and is an easy and cheap technique related to molecular and immunological techniques, which are already used for genetic diversity studies.

\section{ACKNOWLEDGMENTS}

Research supported by the Coordination for the Improvement of Higher Education Personnel, a Brazilian Foundation within the Ministry of Education, and by the National Council for Scientific and Technological Development, a foundation associated to the Brazilian Ministry of Science and Technology.

\section{REFERENCES}

Agrios GN (1988). Plant Pathology. 3rd edn. Academic Press, New York.

Andebrhan T and Furtek DB (1994). Random amplified polymorphic DNA (RAPD) analysis of Crinipellis perniciosa isolates from different hosts. Plant Pathol. 43: -1020.

Andebrhan T, Almeida LC and Nakayama LHI (1998). Resistência de theobroma cacao L. a Crinipellis perniciosa (Stahel) singer: a experiência da amazônia brasileira. Agrotrópica 10: 49-60.

Andebrhan T, Figueira A, Yamada MM, Cascardo J, et al. (1999). Molecular fingerprinting suggests two primary outbreaks of witches' broom disease (Crinipellis perniciosa) of Theobroma cacao in Bahia, Brazil. Eur. J. Plant Pathol. 105: 167-175.

Arruda MCC, Miller RNG, Ferreira MASV and Felipe MSS (2003). Comparison of Crinipellis perniciosa isolates from Brazil by ERIC repetitive element sequence-based PCR genomic fingerprinting. Plant Pathol. 52: 236-244.

Bastos CN and Evans HC (1985). A new pathotype of Crinipellis perniciosa (witches' broom disease) on Solanaceous host. Plant Pathol. 34: 306-312.

Bastos CN and Andebrhan T (1986). Urucum (Bixa orellana): nova espécie hospedeira da vassoura-de-bruxa (Crinipellis perniciosa) do cacaueiro. Fitopatol. Bras. 11: 963-965.

Bradford MM (1976). A rapid and sensitive method for the quantitation of microgram quantities of protein utilizing the principle of protein-dye binding. Anal. Biochem. 72: 248-254.

Dahlberg A (1995). Somatic Incompatibility in Ectomycorrhizas. In: Mycorrhiza: Structure, Function, Molecular and Biotechnology (Varma A and Hock B, eds.). Springer - Verlag, New York, 115-136.

Evans HC (1978). Witches' broom disease of cocoa (Crinipellis perniciosa) in Ecuador. I. The fungus. Ann. Appl. Biol. 89: $185-192$.

Evans HC and Barreto RW (1996). Crinipellis perniciosa: a much investigated but little undertood fungus. Mycologist 10: $58-61$.

Gomes LMC, Melo GRP, Faleiro FG, Silva SDM, et al (2000a). Diversidade Genética de Crinipellis perniciosa na Região Sul da Bahia Utilizando Marcadores Moleculares RAPD. Vol. 1. Proceedings of 13th International Cocoa Research Conference, Sabah.

Gomes LH, Duarte KMR, Argueso JL, Echeverrigaray S, et al. (2000b). Methods for yeast characterization from industrial products. Food Microbiol.17: 217-223.

Griffith GW and Hedger JN (1994a). The breeding biology of biotypes of the witches' broom pathogen of cocoa, Crinipellis perniciosa. Heredity 72: 278-289.

Griffith GW and Hedger JN (1994b). Spatial distribution of mycelia of the liana (L-) biotype of the agaric Crinipellis perniciosa (Stahel) Singer in tropical forest. New Phytol. 127: 243-259.

Griffith GW, Nicholson J, Nenninger A, Birch RN, et al. (2003). Witches' brooms and frosty pods: two major pathogens of cacao. New Zeal. J. Bot. 41: 423-435.

Genetics and Molecular Research 11 (3): 2559-2568 (2012)

CFUNPEC-RP www.funpecrp.com.br 
Hamidson SH and Naito S (2004). Distribution of Rigidoporus lignosus genotypes in a rubber plantation, as revealed by somatic compatibility. Mycoscience 45: 72-75.

Hedger JN, Pickering V and Aragundi J (1987). Variability of populations of the witches' broom disease of cocoa (Crinipellis perniciosa). Trans. Br. Mycol. Soc. 88: 533-546.

Jiménez RMP, Díaz RMJ and Herrera CJL (2002). Somatic incompatibility of Rosellinia necatrix on avocado plants in southern Spain. Mycol. Res. 106: 239-244.

Laemmli UK (1970). Cleavage of structural proteins during the assembly of the head of bacteriophage T4. Nature 227: 680-685.

Lana TG, Azevedo JL, Pomella AW, Monteiro RT, et al. (2011). Endophytic and pathogenic isolates of the cacao fungal pathogen Moniliophthora perniciosa (Tricholomataceae) are indistinguishable based on genetic and physiological analysis. Genet. Mol. Res. 10: 326-334.

Liberato JR, Cruz CD, Vale FXR and Zambolim L (1995). Técnicas Estatísticas de Análise Multivariada Aplicada à Fitopatologia. I. Análise de Componentes Principais, Análise Canônica e "Cluster Análise". Rev. Anual Patol. Plantas - RAPP 3: 227-310.

May G (1988). Somatic incompatibility and individualism in the coprophilous basidiomycete, Coprinus cinereus. Trans. Br. Mycol. Soc. 91: 443-451.

McCabe PM, Gallacher MP and Deacon JW (1999). Evidence for segregation of somatic incompatibility during hyphal tip subculture of Rhizoctonia solani AG 4. Mycol. Res. 103: 1323-1331.

McGeary FM and Wheeler EJ (1988). Growth rates of, and micelial interactions between, isolates of Crinipellis perniciosa from cocoa. Plant Pathol. 37: 489-498.

Meinhardt LW, Rincones J, Bailey BA, Aime MC, et al. (2008). Moniliophthora perniciosa, the causal agent of witches' broom disease of cacao: what's new from this old foe? Mol. Plant Pathol. 9: 577-588.

Novak LA and Kohn LM (1988). Electrophoresis of major proteins in stromata of members of the sclerotiniaceae. Trans. Br. Mycol. Soc. 91: 639-647.

Pereira JL, Ram A, Figueredo JM and Almeida LCC (1989). Primeira ocorrência de vassoura-de-bruxa na principal região produtora de cacau. Agrotrópica 1: 79-81.

Pereira JL, Barreto RW and Bezerra JL (1997). Distribuição de Crinipellis perniciosa em solanáceas selvagens no Sudeste do Brasil. Fitopatol. Bras. 22: 295.

Pereira JL, Barreto RW and Bezerra JL (1998). Ocorrência de Crinipellis sp. em Solanum Mauritianum. In: XXXI Congresso Brasileiro de Fitopatologia, 1998, Fortaleza. Fitopatologia Brasileira. Sociedade Brasileira de Fitopatologia., Brasília, 268.

Pilotti CA, Sanderson FR and Aitken EAB (2002). Sexuality and interactions of monokaryotic and dikaryotic mycelia of Ganoderma boninense. Mycol. Res. 106: 1315-1322.

Purdy LH and Schmidt RA (1996). Status of cacao witches' broom: biology, epidemiology, and management. Annu. Rev. Phytopathol. 34: 573-594.

Resende MLV, Junqueira NTV and Dianese J (1997). Crinipellis perniciosa causando vassoura-de-bruxa em lobeira (Solanum lycocarpum) no Distrito Federal e no estado de Goiás. Fitopatol. Bras. 22: 301.

Resende MLV, Nojosa GBA, Silva LHCP, Niella GR, et al. (2000). Crinipellis perniciosa proveniente de um novo hospedeiro, Heteropterys acutifolia, é patogênico ao cacaueiro. Fitopatol. Bras. 25: 88-91.

Silva SDVM, Luz EDMN and Matsuoka K (1998). Seleção de variáveis na avaliação de progênies de cacaueiro (Theobroma cacao) quanto a resistência a Crinipellis perniciosa. Agrotrópica 10: 87-94.

Thomsen IM and Koch J (1999). Somatic compatibility in Amylostereum areolatum and A. chailletii as a consequence of symbiosis with siricid woodwasps. Mycol. Res. 103: 817-823.

Viana-Júnior CAC (2001). Compatibilidade Somática e Patogenicidade de Crinipellis sp. Master's thesis, Universidade Federal de Lavras, Lavras.

Wheeler BEJ (1976). An Introduction to Plant Disease. John Wiley, London.

Wheeler BEJ and Mepsted R (1988). Pathogenic variability amongst isolates of Crinipellis perniciosa from cocoa (Theobroma cacao L.). Plant Pathol. 37: 475-488.

Yamada MM, Andebrhan T and Furtek DB (1998). Genetic variability among isolates of Crinipellis perniciosa from solanaceous hosts and their relationship to isolates from Theobroma cacao. Agrotrópica 10: 23-126. 